УДК 327

DOI 10.30970/vir.2018.45.0.9458

\title{
ZDOLNOŚCI UNII EUROPEJSKIEJ DO WALKI Z ZAGROŻENIAMI BEZPIECZEŃSTWA MIĘDZYNARODOWEGO
}

\author{
Slawomir Piotrowski \\ Akademia Sztuki Wojennej, \\ al. A. Chruściela 103, Warszawa, Polska, 00-910, tel. 261813 364, \\ e-mails.piotrowski@akademia.mil.pl
}

\begin{abstract}
Zjawiskiem, które niewątpliwie ma znaczenie w procesie kształtowania się nowego środowiska międzynarodowego jest globalizacja. Jedną z ważniejszych cech globalizacji jest wzrost współzależności pomiędzy podmiotami sceny międzynarodowej. Niewątpliwie podmiotem takim jest odgrywająca coraz istotniejszą rolę również na płaszczyźnie politycznej Unia Europejska. Jako jednolity organizm, jawi się ona niewątpliwie, jako partner, mogący aktywnie i skutecznie angażować się w utrzymanie porządku międzynarodowego. Warunkiem jest, w tym wypadku, doprowadzenie do utworzenia wspólnych zdolności militarnych. Dzięki nim Unia Europejska zyskać może skuteczne narzędzie przeznaczone do reagowania na pojawiające się zagrożenia bezpieczeństwa w Europie i jej bezpośrednim otoczeniu.

Celem artykułu jest przedstawienie wkładu jaki Unia Europejska wnosi w walkę z zagrożeniami bezpieczeństwa międzynarodowego. Artykuł rozpoczyna się opisem środowiska bezpieczeństwa międzynarodowego po rozpadzie systemu dwublokowego oraz motywy, które skłoniły państwa tworzącej się Unii Europejskiej do podjęcia wysiłków mających na celu budowę wspólnych niezależnych od NATO zdolności wojskowych. Następnie autor dokonuje opisu zdolności militarnych w zakresie reagowania kryzysowego jakie w ramach Wspólnej Polityki Bezpieczeństwa i Obrony posiada Unia Europejska. W tej części artykułu autor analizując przypadki faktycznego zaangażowania Unii Europejskiej w rozwiazywanie kryzysów podjął próbę oceny stanu gotowości sił, które Unia ma do dyspozycji, oraz faktycznej woli ich użycia w zażegnaniu kryzysów zagrażających bezpieczeństwu Europy w jej bezpośrednim otoczeniu. We wnioskach autor wskazał na głównie niedostatki w sferze decyzyjnej dotyczącej polityki bezpieczeństwa i obrony, których wyeliminowanie pozwoliłoby Unii Europejskiej efektywniej reagować na zagrożenia a tym samym spełniać rolę kreatora środowiska bezpieczeństwa międzynarodowego.
\end{abstract}

Stowa kluczowe: polityka bezpieczeństwa; bezpieczeństwo europejskie; Unia Europejska; współpraca wojskowe w Europie; integracja europejska.

\section{Motywy budowy zdolności militarnych UE}

Zjawiskiem, które niewątpliwie miało znaczenie $\mathrm{w}$ procesie kształtowania się nowego środowiska międzynarodowego było szeroko rozpatrywane zjawisko globalizacji, zarówno w kontekście gospodarczym, ale także politycznym i kulturalnospołecznym. Globalizacja przejawia się większymi możliwościami oddziaływania, ale przede wszystkim wzrostem współzależności pomiędzy podmiotami sceny międzynarodowej. Doprowadziło to do konieczności stawienia czoła w sferze globalnej, takim problemom, jak m.in.: zapobieganie kryzysom finansowym, zagadnieniom zadłużenia zagranicznego, narastaniu nierówności rozwojowych, problemom demograficznym i związanych z nimi zjawiskiem głodu.

(C) Piotrowski Sławomir, 2018 
Nie oznaczało to, że tradycyjne zagrożenia bezpieczeństwa państwa całkowicie zaniknęły. Mająca miejsce, w 1991 r., interwencja wojsk koalicji w Zatoce Perskiej oraz późniejsze konflikty pokazały, że świat wraz z końcem zimnej wojny nie stał się bezpieczniejszy i bardziej stabilny. Przeciwnie stał się mniej przewidywalny i bardziej niebezpieczny.

Aby świat stał się bezpieczniejszy, musi spełniać szereg warunków. Zdaniem wielu ówczesnych polityków europejskich, w szczególności francuskich, nowy system międzynarodowy nie może opierać się wyłącznie na porozumieniu największych państw, na wzór koncertu mocarstw, a w jego instytucjach muszą być odpowiednio reprezentowane wszystkie kraje świata [18, s. 260].

Henry Kissinger, w swojej książce Dyplomacja, decydującą rolę w sprawowaniu porządku międzynarodowego przypisywał grupie mocarstw, której przewodzić miały Stany Zjednoczone [14, s. 890]. W grupie tych mocarstw, obok wspomnianych Stanów Zjednoczonych, znalazły się Chiny, Japonia, Rosja, Indie i Europa, jako jednolity organizm o charakterze gospodarczo-politycznym. Wizja ta, chociaż niepodzielana przez wszystkich wydaje się być realizowana $\mathrm{w}$ rzeczywistości. Dowodem na to może być stopniowa odbudowa przez Rosję strefy wpływów, coraz wyraźniejsze sygnały ze strony Chin w kontekście dominacji na obszarze południowowschodniej Azji oraz pojawiająca się potrzeba reformy Organizacji Narodów Zjednoczonych polegająca, miedzy innymi, na poszerzeniu składu Rady Bezpieczeństwa.

W tym kontekście przyszła Europa, jako jednolity organizm, jawi się niewątpliwie, jako partner, mogący aktywnie i skutecznie angażować się w utrzymanie porządku międzynarodowego. Warunkiem jest, w tym wypadku, doprowadzenie do utworzenia wspólnych zdolności militarnych oraz skutecznej politycznej reprezentacji Unii na zewnątrz. Wprawdzie po zakończeniu zimnej wojny zmniejszyło się znaczenie czynnika militarnego, jednak utrzymywanie się stanu konfliktu w różnych regionach świata sprawiło, iż w wielu państwach dokonuje się przewartościowań w optymistycznej do niedawna ocenie tego trendu [13, s. 307].

Jednym z pomysłów Unii Europejskiej na zaakcentowanie swojej roli jako aktywnego uczestnika zachodzących procesów w środowisku bezpieczeństwa było wypracowanie wspólnej prowadzonej w ramach Unii Europejskiej polityki bezpieczeństwa. Powodem tych starań, pośrednio tylko korespondującym ze sprawami dotyczącymi zdolności militarnych, były i w dalszym ciągu są wyzwania globalizacji, które stanowią obiektywnie zaistniały etap rozwoju cywilizacji wymuszający na podmiotach międzynarodowych konieczność jak najlepszego przystosowania się. Unia Europejska dokonała tego poprzez udaną integrację gospodarczą. Dzięki temu stała się, w ostatniej dekadzie ubiegłego wieku, gospodarczo liczącym się aktorem stosunków międzynarodowych. Aktualnie Unia stara się wypracować podobną pozycję na płaszczyźnie stosunków polityczno-militarnych. Wyzwania globalizacji stanowią oczywiście bardzo istotny powód rozwoju zdolności militarnych, ale nie jedyny i nie najważniejszy a za taki można uznać niewątpliwe zapewnienie bezpieczeństwa oraz konieczność stawienia czoła zagrożeniom różnego typu również tym wymagającym zastosowania siły militarnej. 
O pierwszych poważniejszych zamiarach zwiększenia roli Europy w kształtowaniu bezpieczeństwa na kontynencie można mówić dopiero od podpisania Traktatu z Maastricht w 1992 r. [10, s. 170-171] a następnie Deklaracji w sprawie roli Unii Zachodnioeuropejskiej i jej stosunków z UE i NATO, w którym to dokumencie państwa Europy Zachodniej zawarły stwierdzenie, że «Państwa członkowskie UZE są zgodne, co do potrzeby ustanowienia autentycznej tożsamości bezpieczeństwa i obrony oraz większej odpowiedzialności europejskiej w kwestiach obronnych» [7].

Zmianom politycznym przyświecał cel budowy zjednoczonej gospodarczo i politycznie Europy, przyszłego globalnego gracza mogącego być partnerem dla Stanów Zjednoczonych. Dlatego Unia Europejska - tworząc swój potencjał militarny - powinna zarówno wówczas jak i obecnie definiować ten proces, jako raczej komplementarny niż konkurencyjny wobec NATO i USA [4, s. 27-30]. Wola zwiększania znaczenia Europy również w obszarze bezpieczeństwa urealniła się poprzez ściślejszą integrację państw UE, które tworząc na mocy Traktatu (TUE) z Maastricht Wspólną Politykę Zagraniczną i Bezpieczeństwa (WPZiB), wyrażały gotowość do wypracowywania w przyszłości wspólnej europejskiej obrony [10, s. 170-171]. WPZiB wśród innych polityk Unii Europejskiej zgodnie z art. B Traktatu o Unii Europejskiej była projektem definiowanym, jako podstawa do realizacji i potwierdzenia tożsamości Unii na arenie międzynarodowej.

Wydarzeniami, które zmieniły nastawienie niektórych mocarstw europejskich a tym samym przyspieszyły rozpoczęcie budowy europejskiej autonomii strategicznej, były wojny towarzyszące rozpadowi Jugosławii, a następnie Kryzys Kosowski. Brak jakichkolwiek struktur wojskowych, obnażył z całą mocą w czasie wojny w Bośni nie tyle Unię Europejska, co UZE, ponieważ konflikt wybuchł wcześniej zanim Unia zdołała wypracować choćby prowizorium wspólnej polityki obronnej. Mimo, że nominalnie UZE w czasie wybuchu konfliktu bałkańskiego była w dalszym ciągu autonomiczną organizacją mogącą prowadzić operacje pokojowe, nie zdołała zrobić nic, w celu ustabilizowania sytuacji na obszarach objętych działaniami wojennymi. Nie pomógł w tym nawet fakt rozszerzenia kompetencji UZE w czerwcu 1992 r. o tzw. misje petersberskie [20, s. 23]:

operacje humanitarne i ratownicze,

misje pokojowe,

zadania bojowe przy opanowywaniu sytuacji kryzysowych, w tym przywracania pokoju.

Politycy zachodnioeuropejscy stopniowo zaczęli zdawać sobie sprawę z tego, że uzyskując zdolności reagowania kryzysowego Unia Europejska na arenie międzynarodowej znacznie zyskałaby na znaczeniu. Realizacja misji petersberskich. Stworzenie mechanizmu, który pozwoliłby państwom europejskim na sprawne realizowanie niezależnych od NATO akcji przywracania i utrzymania pokoju a tym samym dałaby Europie Zachodniej zdolność realnego wpływu na środowisko bezpieczeństwa w Europie i poza nią, stało się strategicznym celem Unii Europejskiej.

Wojny toczone w latach dziewięćdziesiątych na terenach byłej Jugosławii były dla Europy podwójną lekcją [15, s. 14]: 
1. Pokazały bezradność jej instytucji międzynarodowych - UE/UZE (także OBWE) - wobec tego rodzaju konfliktu i zagrożenia dla jej bezpieczeństwa. Ponieważ ani UZE, ani UE nie dysponowały odpowiednimi zasobami i instrumentami - dla stawienia czoła kryzysowi, który miał miejsce na jej «własnym podwórku» - Europa potrzebowała Stanów Zjednoczonych. Koniecznym stało się skorzystanie z potencjału militarnego USA. W celu zażegnania kryzysu stworzono koalicję państw pod przewodnictwem Stanów Zjednoczonych, natomiast koncepcje Europejskiej Tożsamości Bezpieczeństwa i Obrony a także Wielonarodowych Połączonych Sił Zadaniowych (CJTF) odłożone zostały na plan dalszy.

2. Amerykanie wcale się nie garnęli do wojskowego zaangażowania na Bałkanach, a ponadto dowodząc w tych operacjach, stosowali taktykę, która polegała na ograniczaniu ryzyka dla własnych żołnierzy. Taktyka osiągnęła swoją kulminację w niemal doktrynalnej postaci «zero strat własnych» w Kosowie, co polegało na bombardowaniu z dużej wysokości i potęgowało straty humanitarne, a tym samym utrudniało poszukiwanie politycznego rozwiązania w kolejnych fazach konfliktu.

Bardzo istotnym impulsem, który nieoczekiwanie podniósł na wyższy poziom koncepcje wspólnych europejskich zdolności militarnych, stała się zmiana stanowiska Wielkiej Brytanii. Ówczesny rząd brytyjski pod przewodnictwem Tony Blair'a stał się ku zaskoczeniu obserwatorów zwolennikiem budowy obrony europejskiej. Zmiana stanowiska zaprezentowana przez premiera Wielkiej Brytanii Tony Blair'a podyktowana była nie tyle zmianą stosunku nowej ekipy rządzącej do UE, co chęcią wyjścia z samoizolacji spowodowanej dotychczasową niechęcią Londynu do wszelkich inicjatyw zmierzających do usamodzielnienia się Europy pod względem militarnym. Zaangażowanie państwa o tak istotnym potencjale militarnym i gospodarczym otwierało przed UE perspektywę stania się aktorem w zakresie bezpieczeństwa [21, s. 105].

Dalej sprawy potoczyły się z dość niezwykłą jak na Unię Europejską szybkością. Przypomnijmy, iż ten proces został uruchomiony w bardzo określonym historycznym kontekście. Był to czas interwencji NATO w Kosowie, zdominowanej bez reszty pod względem politycznym i operacyjnym przez Stany Zjednoczone. W czasie wojny o Kosowo, popierający aktywnie interwencję Europejczycy w tej kwestii pokazali swoją bezsilność i brak skuteczności w prowadzeniu operacji wojskowej, która była przecież «na miarę» Europy. Problem polegał nie tyle na braku potencjału w ogóle, ile w braku instrumentów, które mogłyby ten potencjał aktywnie wykorzystać.

Szczyt NATO-UE, który odbył się w Waszyngtonie w dniach 23-25 kwietnia 1999 r. zaowocował podpisaniem porozumienia zwanego «Berlin Plus», na mocy którego Unia uzyskała prawo dostępu do zasobów i zdolności NATO do prowadzenia operacji bez udziału USA [1, s. 61]. Porozumienie «Berlin Plus» pozwoliło państwom UE do bardziej zdecydowanych działań i skutkowało na zakończenie posiedzenia Rady Europejskiej w dniach 3-4 czerwca 1999 r. w Kolonii ogłoszeniem deklaracji o utworzeniu Wspólnej Europejskiej Polityki Bezpieczeństwa i Obrony. Ponadto przewidziano utworzenie rozległej podstawy organizacyjno-technicznej: od ośrodków analiz, wywiadu, planowania strategicznego, aż po centrum satelitarne i instytut 
studiów bezpieczeństwa; częściowo chodziło o przejęcie już istniejących materialnych aktywów UZE [15, s. 16].

Podczas kolejnego oficjalnego spotkania Rady Europejskiej w Helsinkach w dniach 10-11 grudnia 1999 roku oficjalnie ustanowiono Europejską Politykę Bezpieczeństwa i Obrony, jako narzędzie wykonawcze Wspólnej Polityki Zagranicznej i Bezpieczeństwa [22, s. 110], zdecydowano utworzyć ramy instytucjonalne EPBiO oraz przyjęto Europejski Cel Operacyjny (European Headline Goal - HG) zakładający sformowanie Europejskich Sił Zbrojnych zdolnych do realizacji operacji humanitarnych, reagowania kryzysowego oraz wymuszania pokoju. Zdecydowano o utworzeniu do końca $2003 \mathrm{r}$. sił na poziomie korpusu (60 tys. żołnierzy) zdolnego do działania $\mathrm{w}$ ciągu 60 dni od podjęcia decyzji, przez okres do jednego roku. Siły te miały mieć zdolność do efektywnego działania w misjach wojskowych prowadzonych przez Unię Europejską, zarówno z wykorzystaniem zasobów NATO jak też i bez nich [12, s. 11].

We wszystkich tych sytuacjach Unia Europejska przewidywała działania zgodne z prawem międzynarodowym, czyli uprzednią akceptację Rady Bezpieczeństwa Organizacji Narodów Zjednoczonych lub organizacji regionalnych (np.: OBWE) działających na mocy i zgodnie z rozdziałem VIII Karty Narodów Zjednoczonych. We wszystkich dokumentach programowych UE dotyczących realizacji powyższych misji, mówi się o operacjach na rzecz pokoju, stabilności, powstrzymania katastrof humanitarnych lub zapobiegania im, w tym masowemu naruszaniu praw człowieka [15, s. 20]

Podstawowym celem powstania EPBiO było zbudowanie zdolności do skutecznego zarządzania kryzysami zewnętrznymi. W tym wypadku bodźcem do podjęcia działań stał się sposób, w jaki rozwinął się kryzys w Kosowie. Bodźców, które skłoniły państwa UE do bardziej zdecydowanych kroków w kierunku utworzenia europejskich zdolności militarnych jest więcej. Takim bodźcem były i są nadal - wywodzące się jeszcze $\mathrm{z}$ lat osiemdziesiątych $\mathrm{XX}$ wieku - różnice w sprawach polityki zagranicznej i bezpieczeństwa pomiędzy Europą a USA.

Od samego początku istnienia Europejskiej Polityki Bezpieczeństwa i Obrony, a w szczególności od momentu ogłoszenia Europejskiego Celu Operacyjnego, w Stanach Zjednoczonych oraz $\mathrm{w}$ niektórych europejskich krajach należących do NATO, a niebędących jeszcze członkami Unii, pojawiały się głosy ostrzegające przed duplikowaniem istniejących w NATO zdolności i zasobów wojskowych oraz osłabieniem Sojuszu i więzi transatlantyckiej. Sytuacja taka w wielu wypadkach jest jednak nieunikniona, gdyż, aby dobrze realizować całe spektrum operacji antykryzysowych istnieje potrzeba tworzenia jednostek zdolnych do wykonywania zadań we wszystkich sytuacjach [15, s. 124-125].

\section{Zdolności wojskowe Unii Europejskiej}

Europejczycy zbierali doświadczenia $\mathrm{w}$ integracji wojskowej zanim pojawiła się EPBiO. W 1989 r., jeszcze w ramach UZE, utworzono francusko-niemiecką brygadę, która miała stać się $\mathrm{w}$ pełni rozwiniętą jednostką bojową i służyć, jako model jednostki wielonarodowej [17, s. 86-88]. W praktyce okazało się jednak, że istniejące różnice pomiędzy dwoma armiami były głębsze niż przewidywano. Propagandowo 
atrakcyjny pomysł okazał się raczej chybiony. Zebrane doświadczenia spowodowały rezygnację z pomysłu tworzenia kolejnych mieszanych jednostek międzynarodowych na tym szczeblu [2, s. 100].

Inaczej sytuacja potoczyła się w wypadku Eurokorpusu. Ten, tworzony od 1992 r., wielonarodowy związek operacyjny UZE zdolność do działania uzyskał w 1995 r., a w sześć lat później włączony został do składu natowskich Sił Szybkiego Reagowania (RRF - Rapid Reaction Forces), pozostając jednocześnie w dyspozycji UE i NATO. W skład Eurokorpusu, liczącego 50 tys. żołnierzy wchodziły: dywizja pancerna i pułk z Francji, dywizja pancerna z Niemiec, belgijska dywizja zmechanizowana, brygada hiszpańska, brygada francusko-niemiecka oraz kompania z Luksemburga [2, s. 100].

$\mathrm{Na}$ szczycie w Helsinkach 10-11 grudnia 1999 r., podczas którego Rada Europejska przyjęła Europejski Cel Operacyjny 2003 zaproponowano też utworzenie Sił Szybkiego Reagowania Unii Europejskiej (EU Rapid Reaction Force - EURRF) gotowych do działania w 2003 roku. Siły te miały składać się z ok. 15 brygad o ogólnej liczebności 50-60 tys. żołnierzy zdolnych do działania w rejonach oddalonych do 6 tys. km. Określono również, że siły te miały posiadać zdolność przerzutu w rejon działań w ciągu 60 dni od podjęcia decyzji o ich użyciu. Określono, że siły mają być samowystarczalne pod względem dowodzenia, wywiadu, logistyki i wsparcia a także posiadać komponenty: lądowy, morski i powietrzny [20, s. 47].

Aby sprawnie realizować powyższe zamierzenia UE musi posiadać możliwości do ich planowania i kierowania. Zdano sobie również sprawę że nie będzie to możliwe bez powołania częściowo stałych zespołów i sztabów. To właśnie wtedy zdecydowano utworzyć następujące organy polityczne i wojskowe:

- Stały Komitet Polityczny i Bezpieczeństwa (SKPiB) złożony z przedstawicieli państw członkowskich na szczeblu ambasadorów;

- Komitet Wojskowy złożony z ministrów obrony lub delegowanych przez nich przedstawicieli;

- Sztab Wojskowy UE, powołany do kierowania misjami petersberkimi oraz do planowania strategicznego oraz wczesnego ostrzegania i sporządzania analiz wojskowych.

Na posiedzeniu w marsylii 13 listopada $2000 \mathrm{r}$. Rada Ministerialna UZE podjęła decyzję likwidacji UZE i o przekazaniu do UE wszystkich swoich zasobów, również tych niezbędnych do prowadzenia misji petersberskich, co nastąpiło w 2001 r. Były to [5, s. 97]:

- Komórka Planowania - organ, którego zadaniem było przygotowanie planów użycia sił pod egidą UZE;

- Centrum Sytuacyjne - monitorujące rejony objęte kryzysem oraz postępy w operacji;

- Centrum Satelitarne - zajmujące się analizowaniem przekazów ze źródeł lotniczych i satelitarnych dla celów weryfikacji traktatów, monitorowanie kryzysów i środowiska naturalnego a także szkolenie ekspertów w zakresie interpretacji zdjęć lotniczych;

- Zachodnioeuropejska Grupa ds. Uzbrojenia - mająca rozwijać współprace 10 państw UZE oraz Turcji, Islandii i Norwegii w dziedzinie uzbrojenia; 
- Instytut Studiów nad Bezpieczeństwem - zajmująca się prowadzenia badan nad bezpieczeństwem europejskim.

W Brukseli 20 listopada 2000 r., podczas konferencji dotyczącej zdolności wojskowych Unii Europejskiej, ogłoszono Katalog Europejskich Sił Szybkiego Reagowania, w którym określono wkład poszczególnych państw [9, s. 23]:

- Austria: 2000 żołnierzy;

- Belgia: od 1000 do 3000 żołnierzy, 34 samoloty, 9 okrętów;

- Finlandia: 2000 żołnierzy, 2 okręty;

- Francja: 12000 żołnierzy, 102 samoloty, 15 okrętów;

- Grecja: 3500 żołnierzy, 46 samolotów 1 okręt;

- Holandia: 5000 żołnierzy, do 24 samolotów, 5 okrętów;

- Hiszpania: 6000 żołnierzy, 40 samolotów, 6 lub więcej okrętów;

- Irlandia: 1000 żołnierzy,

- Luksemburg: 1000 żołnierzy;

- Niemcy: 13500 żołnierzy, 93 samoloty, 20 okrętów;

- Portugalia: 1000 żołnierzy, 31 samolotów;

- Szwecja: 1500 żołnierzy, 8 samolotów i 3 okręty;

- Włochy: 6000 żołnierzy, 42 samoloty oraz do 17 okrętów;

- Wielka Brytania: 12500 żołnierzy, 72 samoloty, 18 okrętów.

Swój udział potwierdziły też państwa należące do NATO, a nienależące wówczas do Unii Europejskiej: Czechy, Norwegia, Polska, Węgry, Turcja oraz Słowacja, nienależąca w tym czasie zarówno do NATO jak i UE:

- Czechy: 1000 żołnierzy;

- Norwegia: 1200 żołnierzy;

- Polska: 1500 żołnierzy;

- Słowacja: 350 żołnierzy;

- Turcja: 5000 żołnierzy.

W październiku 2002 ogłoszono, że UE uzyskała zdolność operacyjną do przeprowadzenia pełnego zakresu misji petersberskich, zastrzegając, że istnieją jeszcze pewne ograniczenia, które mogą zostać złagodzone przez dalszy rozwój zdolności wojskowych UE [19, s. 11].

Trudno orzec, $w$ jakim stopniu siły EURRF stanowiły byt realny, a w jakim wirtualny. Stopień zbiurokratyzowania, towarzyszący ich ewentualnemu uruchomieniu oraz manewry odbywające się przy ich tworzeniu będące $\mathrm{w}$ istocie „manewrami papierowymi”, podważały wiarygodność deklaracji o ich gotowości do działań [2, s. 102]. Siły te nigdy nie stały się realne jeszcze z innego powodu a mianowicie, była nim nowa koncepcja, która pojawiła się wśród członków Unii, dotycząca utworzenia grup bojowych (battlegroups) [9, s. 23].

Projekt grup bojowych UE (EGB) zawarty został w opublikowanym dokumencie pt. «Europejski Cel Operacyjny 2010» (EHG $-z$ ang. European Headline Goal 2010) zaakceptowanym przez Radę Europejską na posiedzeniu w dniach 17 18 czerwca 2004. Nowy cel uwzględniał zmiany środowiska strategicznego oraz wnioski wynikające $\mathrm{z}$ dotychczasowych operacji przeprowadzonych przez UE. 
Koncepcja EGB opiera się na francusko-brytyjskiej propozycji przedstawionej $\mathrm{w}$ lutym 2003 roku, dotyczącej utworzenia bardziej elastycznych i mobilnych sił Unii Europejskiej, zdolnych do przerzutu w rejon kryzysu w bardzo krótkim czasie. Koncepcja grup bojowych zakładała utworzenie trzynastu pododdziałów złożonych z około 1500 żołnierzy, zdolnych do rozmieszczenia w promieniu do $6000 \mathrm{~km}$ od Brukseli, zarówno w warunkach pustynnych, w dżungli jak i w terenie górzystym. Każda z grup, w ciągu 10 dni od podjęcia decyzji przez Radę Europejską, miała być w stanie przemieścić się za pomocą własnych środków transportu [11, s. 1-2].

Założono, że grupy bojowe będą zdolne do realizacji misji humanitarnych, pokojowych, wymuszania pokoju oraz misji ewakuacyjnych obywateli UE zgodnie z założeniami misji petersberskich. Grupy przeznaczone są do wykonywania pełnego zakresu zadań zgodnie z artykułem 17.2 Traktatu o Unii Europejskiej oraz zgodnie z założeniami zawartymi w Strategii Bezpieczeństwa Unii Europejskiej [8, s. 2].

Grupy bojowe mogą brać udział w większych operacjach antyterrorystycznych, obok Sił Odpowiedzi NATO pod egidą ONZ lub NATO. Od czasu podjęcia decyzji o tworzeniu grup bojowych Unia Europejska traktuje to przedsięwzięcie, jako najważniejsze w realizacji Wspólnej Polityki Bezpieczeństwa i Obrony. Osiągniecie pełnych zdolności przez niektóre z grup bojowych powoduje, że UE jest gotowa do realizacji misji. Budując zdolności militarne, na bazie doświadczeń z Bałkanów, Kosowa i Afganistanu, Unia Europejska i NATO zdają sobie sprawę, że przyszłym obszarem zainteresowania i troski o bezpieczeństwo będzie cały glob. Jest to niewątpliwie powód, który powinien przenieść współpracę tych organizacji na wyższy poziom. Ówczesny Sekretarz Generalny NATO Jalap de Hoop Scheffer'a, podkreślit, że czas rywalizacji się zakończył a rozpoczęty skoordynowany proces wzajemnego uzupełniania zdolności, ma na celu polepszenie współpracy pomiędzy tymi dwoma organizacjami i uzyskanie jak najlepszego wskaźnika: koszt-efekt [16].

Należy stwierdzić, że zasadność funkcjonowania grup bojowych nie jest ogólnie podważana jednak część ekspertów zgłasza swoje zastrzeżenia co do ich wiarygodności. Na taki stan rzeczy wpływ wywarło kilka zdarzeń dotyczących prób wykorzystania grup bojowych UE, które mogły być użyte przynajmniej w kilku przypadkach operacji prowadzonych przez UE. Jedna z nich była EUFOR - DR Kongo, w 2006 r., wtedy do działań powinna zostać skierowana , pełniąca wówczas dyżur, francusko-niemiecka grupa bojowa. 27 grudnia 2005 r. Sekretarz Generalny ONZ zwrócił się do UE z prośbą o pomoc, w utrzymaniu pokoju w DR Kongo. W niespełna miesiąc po wystosowaniu prośby 23 stycznia 2006 r., podczas szczytu francusko-niemieckiego Niemcy odmówiły zgody na użycie francusko-niemieckiej Grupy Bojowej UE. Oficjalnie Niemcy nie zdecydowały skierować swoich żołnierzy do Afryki ze względu na duże ich zaangażowanie na Półwyspie Bałkańskim oraz w Afganistanie [6, s. 250].

Kolejna okazja na wykorzystanie grupy bojowej UE był kryzys w Darfurze w 2008 r, który spowodował destabilizację w państwach sąsiedzkich - w Czadzie i Republice Środkowoafrykańskiej. Wtedy to Szwecja, jako państwo ramowe «nordyckiej» grupy bojowej, zaproponowała jej wykorzystanie jednak większość państw Unii nie poparła tej inicjatywy. Została przeprowadzona operacja $\mathrm{Z}$ 
wykorzystaniem wielonarodowej grupy ad hoc francusko-polsko-irlandzkiej. Również nie udało się państwom Unii Europejskiej dojść do porozumienia i wesprzeć za pomocą grup bojowych misji w Libii (2011 r.) i w Mali (2012 r.) [3, s. 4].

Powyższe fakty, świadczą o braku jasnych zasad użycia grup bojowych UE oraz niechęci decydentów co $\mathrm{w}$ konsekwencji prowadzi do paraliżu decyzyjnego i ostatecznie nie skutkuje ich wykorzystaniem w rejonie konfliktu. Niezwykle istotnym czynnikiem wpływającym na powściągliwość państw w zakresie kierowania grup bojowych do działań, są niekorzystne zasady finansowania. W ich świetle, to państwa kierujące swoich żołnierzy do operacji reagowania kryzysowego muszą pokrywać ponoszone koszty przynajmniej $90 \%$ tzw. kosztów wojskowych. Wiązałoby się to z koniecznością zmian w systemie finansowania mechanizmu Atena, a także wspólnego wykorzystywania zdolności i zasobów zwłaszcza w dziedzinie zabezpieczenia logistycznego.

Wielu ekspertów uważa, że grupy bojowe są zbyt małe oraz jednocześnie mają ograniczone możliwości do podejmowania działań w znacznej odległości od Europy. Nie są również zdolne do uczestniczenia w klasycznych operacjach utrzymania pokoju (peacekeeping). Istnieje też obawa, że budowanie zdolności wojskowych może stać się celem samym w sobie po to tylko aby udowodnić, że Unia Europejska jest w stanie je zbudować nie mając koncepcji ani woli ich wykorzystania.

Kolejnym problemem w zakresie funkcjonowania grup bojowych jest fakt dublowania ich zadań przez formacje tego typu funkcjonujące równolegle w NATO np. Sił Odpowiedzi NATO (NATO Response Force). Jeszcze inna kwestią, na którą należy zwrócić uwagę jest kwestia jednoczesnego wyznaczania tych samych sił i środków «do dyżurowania» w ramach Grup Bojowych UE oraz zobowiązań wobec NATO. System ich funkcjonowania jest w dalszym ciągu niewydolny, a tym samym nie przyczynił się do wzmocnienia potęgi Unii w aspekcie wojskowym, chociażby z tego powodu, że grupy bojowe nie zostały nigdy użyte. Pomimo tych niedociągnięć na chwilę obecną grupy bojowe są jednym $\mathrm{z}$ najważniejszych osiągnięć Wspólnej Polityki Bezpieczeństwa i Obrony Unii Europejskiej.

\section{Wnioski}

Unia Europejska chce wpływać na otaczające ją środowisko bezpieczeństwa i w pewnym sensie je kształtować poprzez udzielanie pomocy krajom pogrążonym $w$ kryzysach. Należy jednak zauważyć, że nie może ona poradzić sobie z niektórymi wyzwaniami tkwiącymi wewnątrz jej samej. Wyzwania te maja charakter systemowy i strukturalny, które biorąc tylko pod uwagę ostatnia dekadę, uwidocznione zostały z całą mocą w trakcie arabskiej wiosny a następnie w trakcie wydarzeń na Ukrainie. Oczekiwania społeczności międzynarodowej wobec UE i jej potencjalnych możliwości w rozwiazywaniu sytuacji kryzysowych znacznie przewyższają jej faktyczne możliwości.

Na pierwsze miejsce wśród niedostatków, którymi charakteryzuje się działalność UE w sferze polityki bezpieczeństwa wysuwa się brak woli politycznej przejawiająca się $\mathrm{W}$ trudnościach $\mathrm{w}$ znalezieniu wspólnego mianownika pomiędzy państwami członkowskimi. To właśnie brak woli politycznej co do zmian w sferze polityki obronnej skutkował powieleniem w Traktacie Lizbońskim istniejących wcześniej i 
krytykowanych przez wiele państw rozwiązań dotyczących WPBiO. Jedną z takich kwestii wymagających zmiany jest przeniesienie sfery obronności $\mathrm{z}$ poziomu międzyrządowego na poziom unijny a w konsekwencji odejście od zasady jednomyślności $\mathrm{w}$ podejmowaniu decyzji. Niewątpliwie usprawniłoby to proces decyzyjny a w konsekwencji pozwoliłoby UE szybciej reagować na pojawiające się zagrożenia.

Rozwiązania funkcjonujące w odniesieniu do Wspólnej Polityki Zagranicznej i Bezpieczeństwa oraz posiadany potencjał UE pozwala na stwierdzenie, że w dalszym ciągu obszarem, w którym Unia może skutecznie oddziaływać na pojawiające się zagrożenia jest sfera ekonomiczna oraz wykorzystanie narzędzi dyplomatycznych. Sfera militarna to domena NATO. Nie oznacza to, że Unia nie ma w tym obszarze żadnych osiągnięć, posiada przecież grupy bojowe ale brakuje jej konsekwentnej wizji zastosowania posiadanych już zdolności wojskowych.

\section{BIBLIOGRAFIA}

1. Badźmirowska-Masłowska K., Wspólna Polityka Zagraniczna i Bezpieczeństwa Unii Europejskiej. Aspekty prawne i polityczne, Warszawa 2013.

2. Balcerowicz B., Siły zbrojne w państwie i stosunkach międzynarodowych, Scholar, Warszawa 2006

3. Barcikowska A., EU Battlegroups: Ready to Go?, EUISS, 40/2013, https://www.iss.europa.eu/sites/default/files/EUISSFiles/Brief_40_EU_Battlegroups.pdf.

4. Brzeziński Z., Supermocarstwo Unia Europejska a Stany Zjednoczone, [w:] «Rocznik Strategiczny» 2000/2001, red. R. Kuźniar, wyd. Scholar, Warszawa 2001.

5. Ciupiński A., Rozwój Europejskiej Polityki Bezpieczeństwa i Obrony, [w] red. nauk. J. Czaja, Euroatlantycka przestrzeń bezpieczeństwa, Warszawa AON 2005.

6. Ciupiński A., Wspólna Polityka Bezpieczeństwa i Obrony Unii Europejskiej. Geneza, rozwój, funkcjonowanie, Wyd. DIFFIN Warszawa 2013.

7. Deklaracja w sprawie roli Unii Zachodnioeuropejskiej, Bruksela 22 lipca 1997 roku, http://oide.sejm.gov.pl/oide/images/files/dokumenty/traktaty/Traktat_amsterdamski_PL_16.pdf.

8. EU Council Secretariat - FACTSHEET - EU BATTLEGROUPS, EU BG 01, February 2007, http://www.consilium.europa.eu/uedocs/cmsUpload/Battlegroups_February_07-factsheet.pdf.

9. Fishpool M., NATO and EU military capabilities, Cambridgeshire, United Kingdom 2008 r.

10. Gocalski W., Szanse i zagrożenia bezpieczeństwa Polski w perspektywie rozwoju Europejskiej Tożsamości Bezpieczeństwa i Obrony, [w] Współczesne problemy globalne a bezpieczeństwo europejskie, pod red. J. Tymanowskiego, Adam Marszałek, Torun 2001.

11. Headline Goal 2010, http://www.europarl.europa.eu/meetdocs/2004_2009/documents/dv/ sede110705headlinegoal2010_/sede110705headlinegoal2010_en.pdf.

12. Howorth J., J. T. S. Keeler, Defending Europe: the EU, NATO and the quest for European autonomy, New York - Palgrave Macmillan 2003.

13. Informacja rządu o sytuacji międzynarodowej. Wystapienie ministra spraw zagranicznych Andrzeja Olechowskiego w Sejmie, 21 stycznia 1994 r., [w:] R. Stemplowski, Wprowadzenie do analizy polityki zagranicznej, Wydanie drugie rozszerzone, PISM, Warszawa 2007.

14. Kissinger H., Dyplomacja, wyd. Philip Wilson, Warszawa 2002.

15. Kuźniar R., Europejska Strategia Bezpieczeństwa, [w:] Polska w Europie nr 2 (46) 2004.

16. Pop A., NATO and the European Union: Cooperation and security, NATO Review, summer 2007, http://www.nato.int/docu/review/2007/issue2/english/art6.html\#header.

17. Solak J., Niemcy w NATO, Bellona, Warszawa 1999.

18. Szeptycki A., «Pewna wizja świata» - francuska koncepcja ładu wielobiegunowego, [w] Porządek międzynarodowy u progu XXI wieku, pod red. R. Kuźniara, Wydawnictwa Uniwersytetu Warszawskiego, Warszawa 2005. 
19. Thessaloniki European Council 19 and 20 June 2003 Presidency conclusions, dok. PDF, Bruksela 2003, s.11, http://europa.eu/rapid/press-release_DOC-03-3_en.htm.

20. Zięba R., Europejska Polityka Bezpieczeństwa i Obrony, geneza i założenia, Warszawa 2005.

21. Zięba R., Europejska Tożsamość Bezpieczeństwa i Obrony. Polski punkt widzenia, «Stosunki Międzynarodowe», 2001, $\mathrm{nr} 1-2$. 2003.

22. Zięba R., Unia Europejska jako aktor stosunków międzynarodowych, SCHOLAR, Warszawa

Стаття надійшла до редколегії 10.06.2018

Прийнята до друку 01.09.2018

\title{
СИЛИ СВРОПЕЙСЬКОГО СОЮЗУ ДЛЯ БОРОТЬБИ ІЗ ЗАГРОЗАМИ МІЖНАРОДНІЙ БЕЗПЕЦІ
}

\author{
Славомір Пйотровський \\ Академія військового мистеитва, \\ ал. Генерала Грушеля, 103а, м. Варшава, Польща, 00-910, тел. +48-22-261813 364, \\ e-mail s.piotrowski@akademia.mil.pl
}

Явищем, яке безсумнівно має значення у процесі формування нового міжнародного середовища $\epsilon$ глобалізація. Однією 3 найважливіших особливостей глобалізації $є$ зростання взаємозв'язків між суб'єктами на міжнародній арені. Безперечно, організацією, яка відіграє все важливішу роль на політичному рівні $€$ Європейський Союз. Як одностайний організм, вона неодмінно $є$ партнером, здатним активно та ефективно займатися підтримкою міжнародного порядку. У цьому випадку необхідно створити спільні військові сили. Завдяки ним Європейський Союз може отримати дієвий інструмент, спрямований на реагування на виникаючі загрози безпеці в Свропі та їі найближчого оточення.

Мета статті - представити внесок, який Європейський Союз присвячує боротьбі з загрозами міжнародної безпеки. Стаття починається з опису міжнародного безпекового середовища після розпаду двоблокової системи та мотивів, які спонукали держави-члени Європейського Союзу до здійснення спроб щодо створення спільних збройних сил, незалежних від військового потенціалу НАТО. Потім автор робить опис військового потенціалу в області кризового реагування, яким володіє Європейський Союз в рамках Спільної політики безпеки та оборони. У цій частині статті автор, аналізуючи реальні випадки участі ЄС у вирішенні кризових ситуацій, робить спробу оцінити стан готовності сил, що ЄС має в своєму розпорядженні, i бажання їх фактичного використання у врегулюванні криз, які загрожують безпеці Європи в безпосередній близькості. У висновках автор вказує на основні недоліки у сфері прийняття рішень 3 питань безпеки та оборонної політики, усунення яких дозволило б Свропейському Союзу ефективніше реагувати на загрози i, таким чином, виступати в ролі творця середовища міжнародної безпеки.

Ключові слова: політика безпеки; європейська безпека; Європейський Союз; військове співробітництво в Свропі; європейська інтеграція.

\section{CAPACITY OF THE EUROPEAN UNION TO COMBAT WITH INTERNATIONAL SAFETY THREATS}

\author{
Sławomir Piotrowski \\ War Studies University, \\ 103, A. Chruściela Avenue, Warsaw, Poland, 00-910, tel. 261813 364, \\ e-mail s.piotrowski@akademia.mil.pl
}

Globalisation is a phenomenon which is of great importance in the process of formation of a new international environment. One of the most important features of globalisation is an increase of 
interdependence between the entities on the international stage. It is undeniable that one of such entities is the European Union, which is playing more and more important role also on the political plane. As a homogeneous body, it undoubtedly appears to be a partner which may actively and efficiently engage in the maintenance of international order. In this case, there is one condition - creation of common military capabilities. Owing to them, the European Union may gain an effective tool for reacting to the threats to security which occur in Europe and its immediate surroundings.

The aim of the article is to present the contribution that the European Union brings to the fight against threats to international security. The article begins with a description of the international security environment after the collapse of the two-block system and the introduction of the motives that prompted the emerging European Union to undertake efforts to build joint military capabilities independent of NATO. Next, the author describes the military capabilities in the field of emergency response that the European Union has within the framework of the Common Security and Defense Policy. In this part of the article, the author, when analyzing the cases of the actual involvement of the European Union in solving crises, attempted to assess the readiness of forces available to the Union and the actual will to use them to overcome crises that threaten the security of Europe in its close environment. In the conclusions, the author pointed out mainly deficiencies in the decision-making sphere concerning security and defense policy, the elimination of which would allow the European Union to respond more effectively to threats and thus fulfill the role of the creator of the international security environment.

Key words: security policy; European security; European Union; military cooperation in Europe; European integration. 